\title{
The Strategy for Preparing Human Resources in Order to Make It as the Maritims of the World
}

\author{
Muhadi \\ Doctorate Student, Human Resource Management, \\ the State University of Jakarta, Indonesia \\ E-Mail: hadie_11326@yahoo.co.id \\ Hady Efendy (Corresponding Author) \\ Education Practice and Academic Consultant, Indonesia \\ E-mail: efendy_hady@yahoo.co.id
}

Received: Oct. 26, 2017 Accepted: Nov. 14, 2017 Online published: Nov. 15, 2017

doi:10.5296/ijhrs.v8i1.12060

URL: https://doi.org/10.5296/ijhrs.v8i1.12060

\begin{abstract}
Indonesia as the largest archipelagic country in the world has great potential to become the world maritime axis seen from Indonesia's strategic position which is very busy passing the world trade traffic through the sea. The world maritime axis is a strategic idea to put Indonesia's role and function in the international world. Development of maritime sector can also be applied to the nation's commitment in maintaining and managing marine natural resources for the welfare of all Indonesian people. Infra Development The maritime structure can be realized through the connectivity of the archipelago which includes the provision of sea transportation and port facilities are adequate in each region. The development and preparation of maritime human resources is a thing that cannot be denied in supporting the government's vision to realize Indonesia as a maritime axis of the world. This can be realized with the preparation of reliable, professional and competent human resources and supported by technological advances and adequate infrastructure. Various sectors of maritime development are in desperate need of reliable maritime resource availability, this is required by professional maritime sector employment agencies. The preparation of maritime sector human resources in both formal and informal institutions should always be improved both quantitatively in each region and qualitatively supported by adequate infrastructure and technological progress so that the quality of maritime human resources can compete with experts from various country.
\end{abstract}


Keywords: human resource, maritime, leadership, management

\section{Introduction}

Indonesia is the largest archipelagic country in the world consisting of more than 17,504 islands with 13,466 islands that have been named. At this time there are about 92 outer islands as the base line of Indonesia to the open sea which has been registered to the United Nations. Indonesia has $95,181 \mathrm{~km}$ of coastline and lies in a very strategic position between the Asian and Australian Continents as well as the Indian Ocean and Pacific Ocean. As an archipelagic country with the longest ocean and coastline, maritime and maritime sectors become very strategic for Indonesia in terms of economy and environment, social culture, law and security. Indonesia maritime and marine potential is very abundant, requires skilled human resources and have the competence to manage it well so as to improve the welfare of the people of Indonesia.

As the largest archipelago country in the world, Indonesia has great potential to be the axis of the world maritime. Maritime axis of the world is a strategic idea that can be realized to ensure the position of Indonesia in the eyes of the international world. To realize that Indonesia needs human resource development that all oriented to the land (Lond Base Orientsi) into the orientation of marine development (Ocean Orientation). It is not easy to change that orientation, but with the spirit and concrete and radical steps to modernize it is a very workable reality. Starting from the history of the development of the Indonesian Nation as a maritime sailor / nation that has been very well known since the first time we are convinced that the ideals can be realized together to become a strong maritime nation, of course, must be supported by qualified human resources.

As already illustrated in the program delivered in running his administration, President Joko Widodo underscored the importance of infrastructure development and law enforcement in his policy priorities. The first concerns the crucial physical problems facing the country, while the second, related to the weak condition of Human Resources (HR) of Indonesia today. The two crucial problems faced by this nation and nation cannot be separated, because they really involve means, facilitation, or tools, and, again, the human person or factor that does or becomes the force behind it. The involvement of foreign parties in both cases is indispensable and profound, given Indonesia's current limitations in fulfilling it by its own strength. The scarcity of capital due to the diminishing economic growth and the limited ability of the government to develop the power of Human Resources from within the country has created a great need for foreign investment in the development of both sectors. As a consequence, the response of other countries to the policy of world maritime axis being implemented by President Joko Widodo is seen in these two main aspects.

\section{Methodology}

\subsection{Type of Research}

Types of Research This study used a qualitative descriptive research type. Qualitative descriptive research method is a research method based on post positivism philosophy, that is research using descriptive method which describes situation or event where in this research 
does not test hypothesis and do not seek or explain relation and describe actual condition / condition and data obtained from fact -facts that look like the real situation (Sugiyono, 2012). This study is used to examine the natural object conditions in which the researcher is a key instrument and data collection technique, and the results of qualitative descriptive research emphasize the meaning of generalization. Qualitative research has the main purpose of collecting descriptive data that describe the object of research in detail and depth with the intention of developing the concept or understanding of a symptom. This is done because it is based on the fact that there are many things that cannot be revealed only through observation and measurement only (Sandjaja \& Heriyanto, 2006).

\subsection{Research Methods}

This research is a qualitative research with case study approach. This approach was chosen because this study aims to reveal how human resource planning in improving the competence and productivity of employees and how the process of recruitment and selection is done. With this approach the researcher is in a position cannot control the object of research. This research requires the interaction between the researcher and the object of research that is interactive to understand the reality of the object (Esterberg, 2002). Analysis is done by comparing a pattern encountered with a predicted pattern. Here, the propositions that have been formed in the theoretical study serve as a predictable pattern.

This research was conducted by using descriptive-analytical research. The goal is to produce a paper writing that provides a comprehensive and analytical explanation. The approach used for data analysis is a qualitative approach. The method used in the writing of this paper is using literature review method by collecting reference sources related to marine development strategy in Indonesia in Human Resource Setup Strategy to support and realize Indonesia as a World Maritime Axis. They are books, papers / journals, and other articles related to the topics covered in this paper.

\section{Literature Review}

\subsection{Understanding Human Resource Planning}

Human resource planning is the process of anticipating and making provisions to regulate the flow of labor movement inside, inside, and outside the organization, Arthur W. Sherman \& Goerge W Bohlander, in Hadari Nawawi (2005). Meanwhile, according to G. Steiner, said that HR planning is a plan that aims to maintain and improve the ability of the organization in achieving its goals, through the strategy of developing the contribution of its workers in the future. The two definitions mentioned above, while it can be concluded that human resource planning is a series of activities related to the planning effort in anticipating the future.

HR planning as an activity is a process of how to fulfill current and future labor needs for an organization. In meeting the needs of the current workforce, the HR planning process means the effort to fill / close the shortage of labor both in quantity and quality. Meanwhile, in meeting the needs of the workforce in the future, human resources planning more emphasizes the forecasting of the availability of labor based on the needs in accordance with future business plans. In other words, the purpose of HR planning is to use HR as effectively as 
possible in order to have a number of workers who meet the requirements / qualifications in filling vacant positions whenever and wherever they are. With the availability of information about the needs and qualifications desired, then the recruitment, selection, placement, maintenance, development, and welfare of employees will be easier and more controllable.

Meanwhile, according to Safarudin Alwi (2001), it is said that human resource planning is a plan prepared at the operational level proposed to meet the demand of human resources with the required qualifications. Human resource planning is basically needed when business planning as the implementation of the company's vision and mission has been established. The vision of the company as a guide the direction of a business where to go and with what strategy the business will be run. Starting from the business strategy is then what HR planning strategy will be selected. The HR strategy chosen and determined determines what human resource needs to be desired, both in quantity and quality.

While HR planning according to Graham and Benet in Safarudin Alwi (2001), it is said that HR planning as an effort to project how many employees and what kind of organization needed in the future. Actually there are many more definitions about human resource planning that can be lifted, but from some of the definitions mentioned above can generally be concluded that HR planning is the process of determining the needs of human resources, quantitatively and qualitatively to achieve the organization's strategic objectives through MSDM functions in the short term or long term effectively and efficiently.

Mondy \& Noe (2005) define human resource planning as a process that systematically examines the state of human resources to ensure that quantities and qualities with the right skills will be available when they are needed. Eric Vetter in Jackson \& Schuler and Schuler \& Walker in Erni Widajanti (2007) define HR Planning as; the management process in determining the movement of the organization's human resources from its current position to the desired position in the future. Based on the concept, human resource planning is viewed as a linear process, using short-term data and processes as a guide for long-term planning.

In its development, source planning, human resource planning also includes data collection that can be used to evaluate the effectiveness of ongoing programs and provide information to planning for meeting the need for forecast revisions and programs when needed. The main purpose of planning is to facilitate organizational effectiveness, which should be integrated with short-term and long-term organizational goals (Jackson \& Schuler, 1990). Thus, human resource planning is a process of translating business strategy into the needs of human resources both qualitatively and quantitatively through certain stages.

According to Jackson \& Schuler (1990), proper human resource planning requires certain steps relating to human resource planning activities to a modern organization. These steps include:

1. Data collection and analysis to forecast demand and human resource supplies expected for future business planning.

2. Developing human resource planning objectives 


\section{$\triangle 1$ Macrothink}

International Journal of Human Resource Studies

ISSN 2162-3058 2018, Vol. 8, No. 1

3. Design and implement programs that can facilitate the organization for the achievement of human resource planning objectives

4. Overseeing and evaluating the running programs.

These four phases can be implemented on achieving short-term goals (less than one year), medium (two to three years), as well as longer term (more than three years). Rothwell in Erni Wijayanti (2007) offers a human resource planning technique that includes the following stages:

1. Investigation both on external environment, internal, organizational;

2. Forecasting or forecasting the availability of current and future supply and demand of human resources;

3. Planning for recruitment, training, promotion, and others;

4. Utilization, which is intended for the manpower and then provides feedback for the initial process.

\subsection{Supply of $H R$}

Planning the fulfillment of human resources needed is inseparable from the supply available HR. There are two sources of human resources supply, which are internal, derived from existing human resources then re-trained or promoted to fill the void. The internal supply depends on the company's workforce and the level of ability to do the job it offers. While for external sources, can come from college graduates, local job seekers, transfers from other companies, agency providers of labor services, and foreign workers.

\subsection{HR Strategy}

The HR strategy is a set of processes and activities undertaken by HR managers and line managers to solve people-related business issues. Thus HR strategy activities are based on: cooperation between human resources and line managers in managing human resources that emphasize people-related business concerns, to achieve defined business strategy objectives, namely improving current and future business performance and producing sustainable competitive advantage.

There are several complementary facilities that can support the creation of HR strategies, namely:

1. The increasing importance of human resource involvement, this is due to a fundamental change in the business environment. These changes include: a very rapid rate of business change with high uncertainty, rising costs along with increased competitive pressure on profit margins, rapid technological changes that lead to increased demand for new skills through empowerment, education and retraining, increasingly complex (related to product, technology, location, business function, consumer or market), leaner, more flatter and flexible organization, demographic changes with limited labor supply, more concerned with external forces (Law, judiciary, relationships work and others), increased multinational competition and collaboration and multilateral relations. As a result of these changes, some organizations recognize the importance of human beings in business by incorporating them in the corporate 
philosophy and in the strategic planning process.

2. Orientation on issues is a way to provide a framework on HR and the business agenda, this is because key issues can help companies in:

a. Create a "deal" to keep their planning systems flexible at fast changing conditions.

b. The same time giving more roles to HR that may be under more pressure from the environment.

\subsection{Benefits of Human Resource Development}

In the Future Leaders who regularly carry out the process of developing human resource strategies in their organizations will benefit in the form of distinctive capability in some respects compared to those who do not. Benefits of human resource development that are strategic namely:

1. The ability to define opportunities and threats to human resources in achieving business objectives.

2. Can trigger new thinking in looking at human resource issues with the orientation and mendisdik participants and presents the expansion of perspective.

3. Testing the commitment of management to the actions taken so as to create a process for the allocation of resources specific programs and activities.

4. Develop a "sense of urgency" and a commitment to action.

While the operational nature of HR planning can be useful to:

1. Improving the empowerment of human resources to give the best contribution,

2. Aligning HR activities with organizational goals so that every employee / labor can maximize the potential and skills to improve organizational performance,

3. Energy savings, costs, time required, so as to improve efficiency for the welfare of employees / employees. (Nawawi, 2005)

The patterns that can be used in the preparation of organizational human resource strategies in the future, among others, (Schuler \& Walker, 1990):

- Line managers handle human resource activities (strategic and managerial), while human resource administration is handled by the head of the operational technical unit.

- Line managers and employment agencies / human resources share responsibilities and activities, in the context of line managers as owners and human resources as consultants.

- The human resources department plays a role in training managers in human resource practices and raising managers' awareness regarding HR concerns

\subsection{Stages of HR Planning}

According to Jackson \& Schuler (1990), proper human resource planning requires certain steps relating to human resource planning activities to a modern organization. These steps include:

1. Data collection and analysis to forecast demand and human resource supplies expected for future business planning. 


\section{Ml Macrothink}

International Journal of Human Resource Studies

ISSN 2162-3058 2018, Vol. 8, No. 1

2. Developing human resource planning objectives

3. Design and implement programs that can facilitate the organization for the achievement of human resource planning objectives

4. Overseeing and evaluating the running programs.

These four phases can be implemented on achieving short-term goals (less than one year), medium (two to three years), as well as longer term (more than three years).

Meanwhile, the approach used in human resource planning is with action driven, which enables organizations to focus certain sections more accurately or skill-need, rather than performing numerical calculations with large numbers for all parts of the organization. Human resource planning is generally seen as an important feature of the ideal type of MSDM model although in practice it should not always be a top priority. Human resource planning is an essential condition of "business integration" and "strategic," the implications being not the same as "manpower planning" even though the techniques cover the same thing. Manpower planning illustrates the traditional approach in forecasting efforts on whether there is a discrepancy between supply and demand for labor, as well as planning the most appropriate policy adjustment. The integration between aspects of human resource planning for business development should ensure that the needs of human resource planning should be seen as a responsibility.

\subsection{Implementation of HR Planning}

The selection of techniques is a starting point in carrying out various activities related to management style, values and culture as a whole. Some human resource planning techniques can be implemented in the recruitment and career planning process.

\section{a. Recruitment Identification}

the possibility of incompatibility between supply and demand and adjustment through recruitment, was previously seen as a reason for traditional manpower planning. Therefore a new approach is needed that takes into account the combination of employee competencies through their knowledge, skills and attitudes and experience. MSDM planning can serve as a guide and provide future insights for people who need to deliver innovative products or quality services that are focused through business strategy in the recruitment process.

b. Career Planning

This requires understanding of processes integrated into individual characteristics and preferences with implications on: organizational culture, values and styles, business strategies and guidance, organizational structures and changes, reward systems, research and development systems, fiber assessment and promotion systems. Some organizations today emphasize individual responsibility for their own career development. Both formal and informal mentoring systems are introduced to help achieve career development. How far the flexibility and efficiency of an organization is determined by government policies, both fiscal and labor markets.

\subsection{Strategic Human Resource Planning}

Strategic human resource planning is human resource planning which is done by using 
strategies related to surplus personnel and shortage personnel. Strategic human resource planning will be discussed through 5 strategic plans for human resource planning, namely:

1. Restructuring strategies. This strategy is used to reconstruct the work structure and unit of workforce to fit properly. In this study, the things that will be discussed in more depth is focus on results, time efficiency, eliminate activities that do not produce added value, and human empowerment in the distribution of work.

2. Training and development strategies. This strategy is done to improve the ability of employees by taking training conducted by the company. This study will discuss the training of employees about the learning capabilities needed by the company, especially the production department so that the company is able to perform strategic human resources planning.

3. Recruitment strategies. Recruitment strategies can be considered as a way for companies to look for potential employees. The Company reserves the right to determine the desired criteria and strive to find the right and best employee candidate and able to face the work in the future. In this research will be discussed about when to do this plan and how the recruitment process will be done and how the criteria needed by the company in finding new workforce.

4. Outsourcing strategies. This strategy uses the power of an outside workforce for a particular job or for a particular ability in which the company contracts with an organization that provides human resources. This research will discuss more deeply about how the use of outsourcing labor in the company, what are the constraints in outsourcing, and how the impact of outsourcing on the company.

5. Collaboration strategies. Collaboration strategy is considered an indirect strategy because it is outside the boundaries of the organization. This strategy combines employees in one organization with other organizations to address shortage personnel issues. This research will discuss more about the type of collaboration used by the company, the intended target with the collaboration strategy, the share of resources.

\section{Discussion}

\subsection{Realizing Indonesia's Strategy as a World Maritime Axis}

A strong maritime state must be supported by competent human resources and have quality in order to fulfill the human resource empowerment in the field of maritime development. The main objective of maritime development is to uphold the dignity and sovereignty of the state over the territory of the sea and the richness of the resources therein, and to strengthen the unity among the archipelago, Maritime development must be able to realize the equitable distribution of inter-island development, including islands in border areas to reduce or even erase the striking development disporitas between the islands.

The vision of the World Maritime Axis illustrates the understanding of geostrategic in Indonesia in the world arena scene. This departs from the awareness that the future of the world is planning in the Pacific area. The entire world shipping route through strategic channels in Indonesia will be used as a diplomacy approach related to the role of Indonesian strategy in the eyes of the world. Thus, the world maritime axis is the doctrine of present-day 
foreign politics and the future of making Indonesia a maritime axis of the world that welfare the people as well as in the respect of other nations in the world.

In running the vision of Indonesia as a world maritime axis there are 5 pillars that must be built and developed, among others:

1. Commitment to rebuild maritime culture, because Indonesia has a history of maritime triumph namely the glory of the kingdom of Sriwijaya and Majapahit kingdom.

2. The second pillar is a commitment to maintain and manage natural resources of the Sea with focus build food sovereignty through marine and earth products, essentially through the development of fishery industry with fishermen as the main pillar.

3. Commitment to encourage the development of intra-structures by building marine naval connectivity by constructing sea tolls, seaport logistics and shipping industry as well as maritime tourism.

4. Maritime diplomacy by inviting all Indonesian partners to cooperate during the Jokowi-Jk government, Indonesia has discussed maritime development several times with developed countries in the world.

5. As the largest archipelagic country that converges on the two oceans of Indonesia is obliged to build the strength of the sea. The power of the sea with the vast sea territory of Indonesia must develop a great navy force and can be respected by other countries. The strengthening of navy aliesista becomes a priority in realizing this fifth pillar in the maritime defense corridor.

\subsection{Preparation and Development of Human Resources (HR) in Order to Realize Indonesia} as a Maritime Axis of the World

In the competition of challenges and global competition, development of quality human resources (HR) is a strategic capital. Development of human resources in the field of maritime and maritime has a strategic role in managing and utilizing marine natural resources are very abundant. With the ability of human resources who have a reliable competence will be the motor of continuous development of marine sector. The problems of the world and the increasingly complex national problems require us to constantly learn not to stutter against global change. On the quantity side the population of Indonesia is a capital to step up and build maritime and maritime sectors. However, to maintain, manage and improve the productivity of the marine sector requires quality human resources that are ready and have the competence that can be taken into account.

To be a strong maritime country, of course, must be supported by human resources (HR) is competent and qualified. In this case, it is necessary that institutions can prepare and print experts in the field of marine development and maritime professionals for Indonesia to welcome the future with a large maritime component. Maritime institutions are believed to have a very important and strategic role to realize the preparation of reliable human resources.

Human resources is the most important part in running the national economy. As a country with a wealth of marine natural resources are great, Improving the quality of human resources 
in the management of coastal and marine resources absolutely must be prioritized in economic growth. One of the most important factors in moving the wheels of the marine economy is the unavailability of reliable and professional human resources.

In the current era of globalization, competition in various lines of increasingly competitive support of professionals is needed. The development of industry in the maritime sector, professionalism will provide its own advantages for individuals working in the sector and in any sector. Individuals will be more appreciated for being able to increase revenue. The weak capacity of Indonesian human resources in the maritime sector is suspected to be related to the education system implemented so far. Terunitologi all the people of Indonesia can be said as a maritime human resources. But seeing the facts have miss orientation of maritime human resource development need to be formed and modifiedparadigmanya. (The way of view from lana base socio economic development to Marine Socio economic development). Therefore, the government through its apparatus is required to be able to formulate policies on marine management and proper maritime.

To support law enforcement in the sea would require the addition of the fleet of the navy in order to maintain national sovereignty and lawlessness in the territorial waters of our national jurisdiction. Therefore, the development of the shipping industry in the country should be accelerated, by preparing the human resources as experts in the field of marine technology marine.

\subsection{Review of Marine Human Resources}

In the midst of competition and global competition challenges, development of quality human resources (HR) is a strategic capital. Development of human resources in the field of maritime and maritime has a strategic role in managing and utilizing marine natural resources are very abundant. The ability of human resources who have a reliable competence will be the motor of continuous development of marine sector. The problems of the world and the increasingly complex national problems require us to constantly learn not to stutter against global change. The quantity side the population of Indonesia is a capital to step up and build maritime and maritime sectors. However, to maintain, manage and improve the productivity of the marine sector requires quality human resources that are ready and have the competence that can be taken into account.

To be a strong maritime country, of course, must be supported by human resources (HR) is competent and qualified. In this case, it is necessary that institutions can prepare and print experts in the field of marine development and maritime professionals for Indonesia to welcome the future with a large maritime component. Maritime institutions are believed to have a very important and strategic role to realize the preparation of reliable human resources.

The Indonesian transportation society acknowledges that Indonesia is still short of workforce in the shipping industry since it has only $21 \%$ or 1,500 people fulfilled from the needs of 7,000 people per year. In addition to voyage, humanitarian realm of human resources, offshore transportation is one of them is still dominated by foreign workers. Conversely, 
Croatia is surplus human resources in the field of maritime.

Meanwhile, according to the human resources development agency, several human resources issues in marine transportation are as of January 1, 2017, the certificate of Indonesian seafarers must be based on Standards of Training, Certification and Watch keeping (STCW) of 1978 amended in 2010. In addition, in 2015, the country reached 16,000 people and overseas sailors as many as 88,552 people. Then for 2019 , it takes 64,897 domestic sailors and 93,478 overseas sailors. Not to mention, the port of port of human resources which require 6,630 people, 2,155 people for public ports and special terminals or terminals for their own needs and to anticipate the construction of 24 new ports.

Similarly for other sectors. The need for manpower for fisheries is also still lacking despite experiencing a downward trend every year. In 2011, at least fisheries work in fishing sector including sea cultivation was recorded as many as 7,000 individuals.

\subsection{The Problem of Marine Human Resources}

The reliable and international standard of marine human resources is essential to realize the ideals of the Joko Widodo-Jusuf Kalla government that will build the maritime economy and even make Indonesia the world's maritime axis. The readiness of human resources in the field of maritime just a crisis. Currently Indonesia is faced with various problems. Among them, the number and quality of human resources generated by education and training institutions in the maritime field is still low. This is caused by various factors, especially shifting the vision of the nation from maritime to the mainland (continental). This transformation gradually resulted in the young generation's interest in maritime professions declining. Tunas the nation considers working in the maritime field is very risky, high risk, dirty and less prestigious.

Another factor that is also a trigger is the cost of education in the field of maritime is expensive. So that is difficult to reach by society of middle social strata which amounts many, about $60-70 \%$. The next factor that remains a problem is the lack of educators and certified training instructors. Meanwhile, the certificate of competence obtained was not recognized internationally as happened in the field of fisheries. Not to mention, awards to the profession in the field of maritime both in the business world and industry are still low.

If the issues related to education and training in the maritime field are done with the analysis of Strengths, Weaknesses, Opportunities, Threats (SWOT) then the strength and weakness factors (internal) and opportunities and threats (external) are identified first.

There is also a strength (Strength) in question is the support of legislation and its derivatives in the field of maritime against the effort to make Indonesia as a maritime axis of the world. The government's commitment to realize Indonesia become an independent, advanced, strong and national-based maritime state. The existence of ease of information globally (global access information). There are already educational and training institutions under the coordination of the Coordinating Ministry (Kemenko) of the Ministry of Marine Affairs.

While the weakness (weakness) is the number of education and training personnel in the field 
of limited maritime. The number of educators and instructors who are certified in the field of maritime is still minimal. The education and training infrastructure in maritime field has not been standardized. The cost of providing education and training in the field of maritime is still expensive. International recognition of graduates from maritime education and training institutions in Indonesia is relatively low. Indonesia has not been active in ratifying international regulations in the maritime field. The synergies between education and training institutions, both internal ministries and inter-ministries tend to be weak.

Then the opportunity (opportunities), competent labor in the maritime field both in the transportation sector, ports, marine and fisheries, tourism and energy HR is still wide open.

While the threats (threats), the era of globalization is increasingly vigorous both in regional and international scale undermine the maritime world of Indonesia, especially from aspects of human resources.

By maximizing existing strengths, reducing existing weaknesses, taking advantage of existing challenges and mitigating threats from SWOT analysis above, there are 10 strategic steps that can be taken, including the targets.

First, encourage and propose maritime loads to enter the school curriculum, especially for primary to secondary level. So as to encourage the return of the transformation of the nation's vision to a maritime vision that has now shifted to the continental vision.

Assuming conducive national political conditions, coordination with the Ministry of National Education (Kemendiknas), Parliament and related elements are good, smooth, budget allocation is available and sufficient, it is expected that in 2017, martyrdom has entered into the national curriculum. The momentum is now that the Ministry of National Education has stopped the 2013 curriculum for elementary school.

Second, encourage the government to establish new educational and training institutions to meet the unmet human resources shortfall of the institution. The criteria, preferably focus on vocational education. Integrated for all areas of maritime (ministry under the Coordinating Ministry / Coordinating Ministry for the Ministry of Marine Affairs). The curriculum, infrastructure and human resources are of international standard to meet national and international human resources. The assumption is that all coordination with various related parties is running well and funding support is available, then at least 2017 there is permit from research and development institution and higher education. Year 2018 has begun operations while waiting for the construction of buildings and other infrastructure is ready.

Third, the standardization of education and training facilities and infrastructure that already exist in each technical ministry. The focus for the fulfillment of national labor first, new international. The target, no later than 2016, all educational and training institutions in the technical ministries under the coordination of the Coordinating Ministry for the Ministry of Home Affairs has met the standards in accordance with the rules applicable in the field of maritime both nationally and internationally.

Fourth, enhanced cooperation with education institutions and overseas training in the field of 
maritime are accredited and match the character of education and training in Indonesia. The target, in 2019 will be established cooperation with institutions abroad and increased 100\%. This will certainly improve the quality of maritime education and training in Indonesia.

Fifth, strengthening synergies with local governments to collaborate to support funding to improve the quality of human resources through maritime education and training institutions that require substantial funds. For example, through the provision of incentive fees required for certification of a sailor who must pocket three basic certificates namely Basic Safety Training, Seaman Book and Nautica Certificate or Engineering. The target, starting in 2016, there must be a legal umbrella between the central and local governments on mutual agreement to support the funding of education and training in the maritime field.

Sixth, to encourage the government through the relevant ministries to immediately ratify international regulations or conventions such as the Standard of Training Certification and Wacth-Keeping for Fisheries (STCWF), so that Indonesia can get international recognition in the field of marine fisheries. The assumption is that all budget support is available and the coordination between technical ministries is smooth, then by the end of 2015 it has to coordinate with the world organizations that handle the maritime to ratify the rules in the field of maritime.

Seventh, encouraging the government through relevant ministries, especially the Ministry of Manpower and Transmigration (Ministry of Manpower and Transmigration), National Development Planning Agency and Ministry of Finance to issue a salary system improvement policy for fishermen, especially fisheries. At least 4-5 times the minimum regional wage (UMR). Assuming that all coordination is going well, at the latest by early 2017, there is already an official government policy related to the specific salary structure for labor in maritime sector, especially for the lagging fisheries sector.

Eighth, forming a forum of communication forum and maritime training to be a media coordination and evaluation for improving the quality of institutions. In 2016, there should be a workshop of educational communication forum and maritime training that addresses strategic issues for improving the quality of education and training in the maritime field.

Ninth, strengthening the certification program in the field of maritime for human resources who do not have a standard of competence according to the rules referred. The assumption, if good coordination, intensive and sufficient funding support, then at the end of 2016, as many as 510.664 Indonesian seafarers are certified Standard of Training Certification and Watch-Keeping for Fisheries (STCW). Thus, all seafarers are not without certificates (illegal).

Tenth, conduct the maritime job fair periodically as a container for the workers to obtain information and find work. The hope, starting in 2016, job fair must be entered into the annual agenda of each technical ministry under the coordination of the Coordinating Ministry of Marine Affairs.

Of the ten strategic steps proposed, then some efforts such as the numbers 1,2, 5 and 6 can be a priority program (quick win), so that can be felt by the community within a relatively short 
time.

\subsection{Strategic Steps in the Preparation of Marine Human Resources}

In the current era of globalization, competition in various lines of increasingly competitive support of professionals is needed. In addition to industry development in the maritime sector, professionalism will provide its own advantages for individuals working in the sector and in any sector. Individuals will be more appreciated for being able to increase revenue. The weak capacity of Indonesian human resources in the maritime sector is suspected to be related to the education system implemented so far. Terunitologi all the people of Indonesia can be said as a maritime human resources. But seeing the fact that there has been a wrong orientation in Maritime Human Resource Development and need to be formed and changed paradigm (outlook) from socio economic development base to become socio economic development. Therefore, the government through its apparatus is required to be able to formulate policies on marine management and proper maritime.

There are 4 (four) things that need to get attention to build maritime sector and maritime in the future. These include the sustainability of natural resources at sea, especially fish resources and wealth, reliable human resources support and calculated competency standards, marine infrastructure development and maritime to support maritime connectivity, as well as institutional maritime systems that support the view of the sector maritime.

The existence of a competent and competent human resources become the key to the successful development of marine and maritime sector, because it is time for Indonesia to have the grand design maritime development and maritime in favor of human resources development in Indonesia in the future Indonesia will be more advanced if supported by good human resources and responsible. In addition to the need to continue to develop new entrepreneurs-based marine resources. This is in the potential of marine resources for the welfare of the community and environmental sustainability as there are many business potentials in this field that need to be developed. The many ministries integrated with the maritime axis of the world, it appears that the Ministry of Marine Affairs and Fisheries (KKP) has demonstrated real performance by capturing and detonating illegal fishing vessels in the waters of Indonesia's national jurisdiction. Minister Susi Pujiastuti and the navy are very eager to uphold sovereignty and lawlessness in Indonesian territory.

To support law enforcement in the sea would require the addition of the fleet of the navy in order to maintain national sovereignty and lawlessness in the territorial waters of our national jurisdiction. For that development of the domestic shipping industry should be accelerated, by preparing human resources as experts in the field of marine technology.

The maritime development sectors can be grouped into seven categories which include:

1. As a sailor of domestic commercial ships and foreign ships.

2. As a domestic and foreign fishing boat catcher.

3. As a sailor on the ministry of the people.

4. Modern fishermen with a variety of marine technology support and cultivation.

5. Labor on offshore sea exploration activities. 
6. Employee / entrepreneur on ecotourism activities

7. Employees in the field of port and management syahbandar.

It all requires the preparation of human resources both in quality and quantity so that our maritime human resources can compete. Institutions as a provider of maritime energy should also be prepared with adequate infrastructure to meet the needs of maritime human resources in the future. Educational institution which is one place to prepare the availability of human resources of the maritime must be prepare and provide an understanding of maritime development orientation concretely. One such approach is the cultural approach that can transform our mindset as a maritime nation through:

1. Education and public procurement of marine and maritime through all channels, types and levels of education.

2. Preserving cultural values and marine insight and revitalizing customary laws and local wisdom in the field of marine.

3. Protecting and socializing maritime cultural heritage through preservation, restoration and conservation efforts.

In addition to the education sector that must be considered one of the sectors of the preparation of human resources in great demand, for example in the maritime tourism sector. Creating quality human resources directly in the field of marine tourism. The preparation of human resources in maritime tourism should always be developed which includes human resources skills, innovation skills, adaptability in facing the sharing of external environmental changes, work culture and education level and level of understanding of the problems of strategy and concepts to be implemented. Therefore, the future of human resources in innovation will be very important in line with the importance of marine natural resources and capital.

Estimated total revenue that can be obtained from various marine sectors and activities reach Rp. 12.7 trillion / year. But the income generated by HR will still increase with assumptions that include:

a. If the number of professional workers increases through the education and training of naval and educational skills of domestic experts in sea exploration activities also increases.

b. The increasing number of catching vessels, passenger ships and cargo vessels as well as an increase in the domestic manufactured and intra-ship shipbuilding sectors increased.

c. Reduction of foreign workers in the construction sector of marine and maritime.

d. Capacity building and modernization of fishing equipments and fishing vessels. This should be supported by modern technological improvements and fishing systems.

e. Professional marine education equipped with adequate technology and infra structure in accordance with the demands and development of marine technology.

f. Preparation of marine tourism development resources that can adequately the needs of marine tourism industries with a variety of wealth and beauty of marine tourism areas of Indonesia are already known in foreign countries. 


\section{Conclusion}

Indonesia as the largest archipelagic country in the world, has great potential to become the world's maritime axis viewed from the strategic position of Indonesia which lies between two continents of Asia and Australia and in position between two Indian oceans and Pacific Ocean with the Indonesian archipelagic sea lanes are very busy traffic passing traffic the world through the sea. The world maritime axis is a strategic idea to put Indonesia's role and function in the international world. This can be realized by re-awakening the spirit and maritime culture of the Indonesian nation with the historical background of the glory of the archipelago kingdoms such as Sriwijaya and majapahit. Development of maritime sector can also be applied to the nation's commitment in maintaining and managing marine natural resources for the welfare of all Indonesian people. Infra development the maritime structure can be realized through the connectivity of the archipelago which includes the provision of sea transportation and port facilities are adequate in each region. Increasing maritime diplomacy with developed countries to work together is equally important for the development of maritime defense by strengthening the navy and air force in protecting national interests and defending the sovereignty and law enforcement in the territorial sea of Indonesia's national jurisdiction. The development and preparation of maritime human resources is a thing that can not be denied in supporting the government's vision to realize Indonesia as a maritime axis of the world. This can be realized with the preparation of reliable, professional and competent human resources and supported by technological advances and adequate infrastructure. Various sectors of maritime development are in desperate need of reliable maritime resource availability, this is required by professional maritime sector employment agencies. The preparation of maritime sector human resources in formal and informal education institutions should always be improved both quantitatively in every district and in kulaitatfi supported by adequate infrastructure and technological progress so that the quality of maritime human resources can compete with experts from various country. With the increasing ability of reliable human resources of course can increase the productivity of marine and maritime development which in the end will increase the nation's economy.

\section{Reference}

Allyn, \& Bacon, N. H. (2001). Manajemen Sumberdaya Manusia, Yogyakarta, Gadjah Mada University Press.

Arif, H. O. (2014). "Dialogue and Cooperation in Maritime Security of ASEAN and ASEAN Regional Forum,” Jakarta: Department of Foreign Affairs of Republic of Indonesia.

"Bakamla dan Poros Maritim Dunia Dunia," makalah disampaikan dalam FGD di P3DI Setjen DPR, pada 11 Maret 2015.

Erni, W. (2007). Perencanaan Sumberdaya Manusia Yang Efektif: Strategi Mencapai Keunggulan Kompetitif. Jurnal Ekonomi dan Kewirausahaan, 7(2), 105-114.

Esterberg. (2002). Qualitative Methods in Social Research. New York: McGraw Hill. 


\section{Macrothink}

International Journal of Human Resource Studies

ISSN 2162-3058 2018, Vol. 8, No. 1

Jackson, S. E., \& Schuler, R. S. (1990). Human Resource Planning: Challenges for Industrial/Organization Psychologists. New York, West Publishing Company. https://doi.org/10.1037/0003-066X.45.2.223

Makmur, K. (2009). Keamanan Maritim dan Implikasinya bagi Indonesia. Jurnal Ilmu Sosial dan Ilmu Politik, 13(1), 111-129.

Mondy, R. W., \& Noe, R. M. (2005). Human Resource Management. International Edition, 9th Edition, Prentice Hall.

Nawawi, H. (2005). Manajemen Sumber Daya Manusia Untuk Bisnis yang Kompetitif. Cetakan Keempat. Penerbit Gajah Mada University Press, Yogyakarta.

"Penanggulangan Maritime Transnational Organized Crimes Menuju Visi Indonesia sebagai Poros Maritim Dunia Dunia.” Kementerian Luar Negeri, 2 Maret 2015.

Rhenal, K. (2005). Change. Gramedia, Jakarta.

Routledge, S. R. S., \& Walker, J. W. (1990). Human Resource Strategy: Focusing on Issues and Actions. Organizational Dynamics, New York, West Publishing Company.

Sugiyono. (2012). Metode Penelitian Pendidikan: Pendekatan Kuantitatif, Kualitatif, dan R\&D. Bandung: Alfabeta.

Sandjaja, B., \& Heriyanto, A. (2006). Panduan Penelitian. Jakarta: Prestasi Pustakaraya.

Safarudin, A. (2001). Manajemen Sumber Daya Manusia. BPFE UGM, Yogyakarta.

"Visi Poros Maritim Dunia: Konsep, Kebijakan dan Tantangan," makalah disampaikan dalam FGD dengan P3DI Setjen DPR, 11 Maret 2015, Jakarta: Direktur Pertahanan Keamanan, 2015.

\section{Copyright Disclaimer}

Copyright for this article is retained by the author(s), with first publication rights granted to the journal.

This is an open-access article distributed under the terms and conditions of the Creative Commons Attribution license (http://creativecommons.org/licenses/by/4.0/). 